\title{
Analisis Jalur Pengetahuan, Intensitas Penyuluhan terhadap Persepsi Peternak pada Penggunaan Serbuk Daun Nangka sebagai Obat Cacing pada Domba
}

\section{Knowledge as a Mediation of the Intensity of Counseling on the Farmers' Perceptions of the Use of Jackfruit Leaves Extract as Anthelmintic in Sheep}

\author{
Nurdayati*), Budi Purwo Widiarso, Dhestalia Eka Pratiwi, Fabiana Mentari Putri Wijaya
}

\author{
${ }^{1}$ Program Studi Penyuluhan Peternakan dan Kesejahteraan Hewan, Politeknik Pembangunan Pertanian Yogyakarta- \\ Magelang, Magelang 56192, Indonesia \\ ${ }^{*}$ E-mail korespondensi: $\underline{\text { nurd4y4t1@gmail.com }}$
}

Diterima: 16 Oktober 2020 | Disetujui: 16 Maret 2021 | Publikasi Online: 22 Maret 2021

\begin{abstract}
The study was carried out in Banter Hamlet, Gumelem Village, Pakis District, Magelang District. The purpose is to determine the farmers' perceptions about the prevention of Haemonchosis using jackfruit leaves powder and to determine the effect of the counseling intensity and the knowledge level of farmers on farmers' perceptions. A sampling of 32 breeders from Ngudi Rejeki 1 Farmer Group was carried out using census method. Data collection techniques were carried out by observation and interview methods. This study was conducted by descriptive analysis using Likert scale to determine the perception level and path analysis to see the perception effect as an endogenous variable with the counseling intensity and knowledge level as exogenous variables. Based on the study, it can be concluded that the descriptive analysis shows farmers' perceptions about the prevention of Haemonchosis using jackfruit leaves powder is in the agree category. The path analysis shows that the counseling intensity does not have a direct effect on perceptions while indirectly from the counseling intensity through the knowledge level significantly influence the perception, so that the knowledge can be said to mediate the counseling intensity on the perception.
\end{abstract}

Keywords: Anthelmintic, counseling intensity, jackfruit leaves, knowledge level, perception

\section{ABSTRAK}

Kegiatan penelitian dilaksanakan di Dusun Banter Desa Gumelem Kecamatan Pakis, Kabupaten Magelang. Tujuan penelitian ini adalah mengetahui persepsi peternak tentang pencegahan penyakit Haemonchosis menggunakan serbuk daun nangka dan pengaruh intensitas penyuluhan serta tingkat pengetahuan peternak terhadap persepsi peternak. Pengambilan sampel sejumlah 32 peternak dari Kelompok Tani Ngudi Rejeki dilakukan dengan menggunakan metode sensus atau sampel jenuh. Teknik pengambilan data dilaksanakan dengan metode observasi dan wawancara. Penelitian ini dilaksanakan dengan analisis secara deskriptif menggunakan skala Likert bertujuan untuk mengetahui tingkat persepsi dan analisis jalur (path analysis) untuk melihat pengaruh antara persepsi sebagai variabel endogen dengan intensitas penyuluhan dan tingkat pengetahuan sebagai variabel eksogen. Berdasarkan hasil penelitian dapat disimpulkan bahwa analisis deskriptif menunjukkan persepsi peternak tentang pencegahan penyakit Haemonchosis menggunakan serbuk daun nangka berada pada kategori setuju. Analisis jalur menunjukkan hasil bahwa intensitas penyuluhan tidak menunjukkan pengaruh secara langsung terhadap persepsi, sedangkan intensitas penyuluhan melalui tingkat pengetahuan berpengaruh signifikan secara tidak langsung terhadap persepsi sehingga dapat dikatakan bahwa pengetahuan memediasi intensitas penyuluhan terhadap persepsi.

Kata kunci: Daun nangka, intensitas penyuluhan, obat cacing, persepsi, tingkat pengetahuan

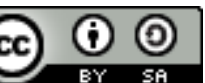

Content from this work may be used under the terms of the Creative Commons Attribution-ShareAlike

4.0 International. Any further distribution of this work must maintain attribution to the author(s) and the title of the work, journal citation and DOI.

Published under Department of Communication and Community Development Science, IPB University and in association with Perhimpunan Ahli Penyuluhan Pembangunan Indonesia.

E-ISSN: 2442-4110 | P-ISSN: 1858-2664 


\section{PENDAHULUAN}

Domba adalah salah satu ternak yang menghasilkan daging serta masih berpotensi untuk dikembangkan. Selain memiliki peluang untuk dikembangkan, domba juga relatif mudah dalam manajemen pemeliharaannya. Potensi ternak kambing dan domba dengan syarat perawatan dan pemeliharaan yang baik secara langsung akan menghasilkan produktivitas yang baik pula (Widiarso et al., 2017). Aspek kesehatan ternak harus diperhatikan agar dapat berproduksi dengan baik. Salah satu penyakit yang sering menyerang ternak domba adalah infeksi parasit cacing nematoda. Parasit yang umumnya menginfeksi ternak domba adalah haemonchosis. Penyakit ini disebabkan oleh cacing Haemonchus contortus yang mempunyai kebiasaan menghisap darah. Cacing ini memiliki tingkat prevalensi mencapai $80 \%$. Tingkat pervalensi cacing Haemonchus contortus disebabkan oleh beberapa faktor yaitu iklim tropis, cara pemeliharaan yang belum baik dan kurangnya kesadaran akan pentingnya kesehatan ternak. Program kesehatan ternak dalam hal ini pengendalian penyakit cacing dapat dilaksanakan dengan memberikan obat cacing secara kontinu. Akan tetapi, pemberian obat cacing secara terus menerus akan mengakibatkan resistensi obat terhadap ternak. Selain itu, obat cacing belum begitu populer di kalangan masyarakat mengingat harga yang masih mahal dan akan menambah biaya pemeliharaan. Salah satu bahan alternatif untuk pencegahan infeksi cacing adalah dengan serbuk daun nangka. Daun nangka adalah salah satu tanaman hasil pertanian yang hanya dimanfaatkan sebagai pakan ternak. Daun nangka mengandung senyawa flavenoid dan enzim bromelin yang memiliki daya anthelmetik atau sebagai obat cacing ternak.

Berdasarkan data Identifikasi Potensi Wilayah (IPW) serta informasi yang diperoleh dari Balai Peyuluhan Pertanian (BPP) Kecamatan Pakis bahwa sektor peternakan domba di Desa Gumelem memiliki potensi untuk dikembangkan. Dalam pengembangan potensi tersebut, peran sumber daya manusia (SDM) yang memadai sangat diperlukan. Dalam hal ini, terbatasnya pengetahuan peternak tentang pencegahan penyakit merupakan salah satu faktor penghambat dan merupakan suatu masalah yang harus ditangani. Penyuluhan pertanian merupakan suatu proses pemberdayaan petani peternak beserta keluarganya melalui proses pendidikan non formal dibidang pertanian yang bertujuan untuk meningkatkan pengetahuan, sikap serta keterampilan petani peternak sehingga diharapkan dapat meningkatkan pendapatan dan kesejahteraan hidup petani.

Penyuluhan berperan sebagai sarana penyampaian informasi dari suatu inovasi teknologi. Menurut Kusnadi (2011), penyuluhan merupakan upaya penyampaian informasi terkait suatu bidang pada pelaku usaha pertanian dan keluarganya, dapat dilakukan secara langsung dan tidak langsung sehingga sasaran mengetahui, bersedia, dan dapat menerapkan suatu inovasi atau teknologi yang dianggap baik. Pada hakekatnya, setidaknya dalam penyuluhan mengandung lima unsur yaitu proses pembelajaran, subyek yang belajar, pengembangan kesadaran dan kapasitas diri maupun kelompok, pengelolaan sumberdaya, dan diterapkannya prinsip keberlanjutan (Amanah, 2007).

Kegiatan penyuluhan adalah sebagai penyampaian informasi yang dapat menimbulkam persepsi peternak dari materi yang disampaikan. Persepsi merupakan gambaran awal peternak terhadap suatu inovasi dalam hal ini adalah penggunaan obat cacing dari serbuk daun Nangka. Faktor-faktor yang mempengaruhi persepsi peternak dapat berasal dari faktor individu peternak itu sendiri atau lingkungan dimana peternak berada. Persepsi peternak banyak dipengaruhi oleh intensitas penyuluhan dan tingkat pengetahuan peternak akan teknologi. Intensitas penyuluhan yang dimaksud merupakan timbal balik antara penyuluh dan peternak itu sendiri, jika penyuluh proaktif, maka secara otomatis pengetahuan peternak akan meningkat. Dipihak lain, peran peternak secara sadar akan meningkatkan pengetahuan yang terus dikembangkan, sehingga tingkat adopsi terhadap suatu teknologi dalam hal ini penggunaan serbuk daun nangka sebagai obat cacing pada domba akan berjalan searah di masa yang akan datang. Menurut Mwirigi et al. (2009) menyatakan bahwa keberadaan teknologi dapat disampaikam melalui kegiatan penyuluhan harus terus ditingkatkan sehingga pandangan dan pengetahuan peternak akan semakin baik di masa yang akan datang. Dilain pihak, Menurut Rahayu et al. (2013) peningkatan pengetahuan peternak harus berjalan searah dengan pengembangan teknologi pada suatu daerah, sehingga dengan demikian pengetahuan merupakan sebuah faktor yang dapat mempengaruhi persepsi peternak pada suatu teknologi. Frekuensi petani dalam mengikuti penyuluhan yang meningkat disebabkan karena penyampaian yang menarik dan tidak membosankan serta yang disampaikan benar-benar bermanfaat bagi petani untuk usaha taninya (Narti, 2015). Lebih lanjut menyatakan bahwa semakin sering petani mengikuti penyuluhan, maka petani akan semakin mengerti dan memahami informasi yang diberikan. Selain itu, melalui penyuluhan maka pengetahuan, 
keterampilan, dan pengalaman dapat bertambah. Menurut Marzuki (2010), peran utama bagi penyuluh pertanian adalah penyuluh sebagai penasehat/advisor, penyuluh sebagai teknisi, penyuluh sebagai penghubung/middleman, penyuluh sebagai organisatoris dan penyuluh sebagai agen pembaharuan.

Intensitas penyuluhan merupakan frekuensi petani mendapatkan informasi yang dibutuhkannya. Intensitas penyuluhan sangat berperan dalam peningkatan pengetahuan petani. Oleh karena itu, peran petani secara partisipatif dan penyuluh haruslah bersinergi dengan baik, sehingga dampak dari penyuluhan itu sendiri dapat terlihat secara maksimal (Sunandar et al.,2020). Persepsi peternak bisa digunakan sebagai tolak ukur keberhasilan peningkatan perilaku dan sikap peternak akan proses adopsi teknologi penggunaan serbuk daun nangka sebagai obat cacing pada domba. Oleh karena itu, jika persepsi baik, maka perbuatan dan sikap akan berjalan baik pula. Peningkatan persepsi peternak harus secara sadar dikembangkan untuk menunjang peningkatan sikap peternak terhadap pengelolaan sebuah teknologi penggunaan serbuk daun nangka sebagai obat cacing pada domba.

Penelitian tentang faktor-faktor yang dapat meningkatkan persepsi sudah banyak dilakukan antara lain Novayanti et al. (2017) menyatakan bahwa persepsi masyarakat dapat dipengaruhi oleh pendidikan formal dan informal, luas lahan, pendapatan, informasi, dan intesitas penyuluhan. Kecenderungannya adalah semakin tinggi pendidikan, maka persepsi juga akan semakin tinggi, demikian juga dengan ketersediaan informasi dan intensitas penyuluhan. Berbeda dengan luas lahan, semakin sempit luas lahan makan persepsi akan semakin tinggi. Sundari et al. (2015) mengungkapkan peran penyuluh pertanian berpengaruh nyata terhadap produksi usahatani padi di Kabupaten Pontianak. Faktor yang berhubungan kuat dan signifikan dengan persepsi adalah tingkat pengetahuan masyarakat tentang lumbung pangan (Dwirayani dan Suciati, 2017).

Berbagai uraian mengenai persepsi peternak, intensitas penyuluhan dan pengetahuan telah dilakukan untuk itu pada penelitian perlu diteliti tentang tingkat pengetahuan sebagai memediasi intensitas penyuluhan terhadap persepsi peternak pada penggunaan serbuk daun nangka sebagai obat cacing pada domba.

\section{METODE PENELITIAN}

Kegiatan penelitian ini dilaksanakan tanggal 2 Maret sampai dengan 2 Mei 2020 yang berlokasi di Desa Gumelem, Kecamatan Pakis, Kabupaten Magelang. Kegiatan penelitian menggunakan teknik one shoot case study. Artinya penelitian satu kelompok dilakukan dengan sekali perlakuan dan selanjutnya dilakukan kegiatan pengambilan data/observasi (Sugiyono, 2014). Pengambilan data menggunakan instrumen/alat berupa kuesioner.

Pendekatan yang dilakukan dalam penelitian ini merupakan pendekatan multimetodologi, yaitu merupakan pendekatan gabungan (mixed methods research), yaitu menggabungkan metode kualitatif dan kuantitatif. Penelitian ini memiliki kecenderungan paradigma pragmatik yaitu penelitian yang didasari oleh orientasi pada masalah. Muslim (2016) menyatakan bahwa pendekatan metode gabungan digunakan pada penelitian yang dalam pendekatannya menggabungkan pengumpulan dan penganalisisan data secara kuantitatif dan kualitatif.

Penelitian ini menggunakan peternak domba yang tergabung dalam kelompok tani Ngudi Rejeki 1 sebagai populasi. Pengambilan populasi dilakukan menggunakan teknik acak bersyarat atau purposive random sampling. Persyaratan yang digunakan dalam pengambilan sampel adalah warga Desa Gumelem dan memiliki ternak domba minimal dua ekor, tergabung dalam kelompok tani Ngudi Rejeki 1 dan mau menikuti kegiatan penyuluhan tentang pemanfaatan serbuk daun nangka sebagai obat cacing dan peternak mau dijadikan responden penelitian.

Sampel merupakan sebagian dari populasi dalam suatu penelitian. Arikunto (2012) menyatakan bahwa disaat subjek penelitian kurang dari 100 unit (orang), lebih baik menggunakan metode sensus dengan mengambil semua sampel yang ada sehingga penelitian menjadi penelitian populasi. Metode sensus dapat diketahui gambaran sebenarnya dari keadaan/karakteristik populasi, sehingga sampel yang digunakan merupakan populasi dari Kelompok Tani Ngudi Rejeki Desa Gumelem Kecamatan Pakis yang berjumlah 32 peternak.

Berdasarkan jenisnya, data yang digunakan dalam penelitian ini adalah data kuantitatif dan data kualitatif, untuk mengukur tingkat pengetahuan, intensitas penyuluhan dan persepsi peternak pada penggunaan serbuk daun nangka sebagai obat cacing pada domba menggunakan data kualitatif yang 
dikuantitatifkan, sedangkan data jumlah peternak yang akan atau pernah menggunakan obat cacing merupakan data kuantitatif. Berdasarkan sumbernya, data yang diperoleh meliputi data primer dan data sekunder. Pengumpulan data primer dilakukan melalui wawancara langsung dengan peternak. Data primer berupa data karakteristik responden dan data hasil post-test, data ini digunakan untuk mengukur persepi peternak. Secara keseluruhan, data primer didapatkan dengan mengobservasi dan mewawancarai peternak secara langsung menggunakan kuesioner yang telah diuji validitas dan reliabilitasnya. Data umum atau sekunder merupakan data mengenai keadaan lokasi penelitian, meliputi monografi, potensi permasalahan, populasi ternak, dan jumlah peternak di Desa Gumelem. Data sekunder digunakan untuk penentuan sasaran, materi, metode, teknik penyuluhan yang terkait dengan hal-hal yang mendukung kegiatan penelitian. Sumber data sekunder yang peneliti ambil adalah Kelompok Tani, Balai Desa Gumelem, Balai Penyuluhan Pertanian Kecamatan Pakis, Kantor Kecamatan Pakis, dan Badan Pusat Statistik Kabupaten Magelang.

Analisis data dilakukan guna mempermudah pembacaan data melalui proses pengolahan dan penyederhanaan data. Kegiatan analisis data meliputi: perekapan data, analisis dan interpretasi data, serta skala pengukuran. Analisis data yang digunakan dalam penelitian ini adalah analisis deskriptif dan analisis jalur (Path analysis). Pendeskripsian hasil evaluasi untuk aspek intensitas penyuluhan, tingkat pengetahuan dan persepsi peternak dianalisis secara deskriptif. Analisis path digunakan untuk menganalisis pengaruh secara langsung variabel intensitas penyuluhan dan variabel tingkat Pengetahuan terhadap variabel persepsi dan selanjutnya melihat pengaruh antara variabel intensitas penyuluhan dan variabel tingkat pengetahuan terhadap variabel persepsi secara tidak langsung.

Analisis data yang digunakan dalam kegiatan ini adalah analisis deskriptif yaitu suatu jenis penelitian yang bertujuan menggambarkan atau melakukan deskripsi angka-angka yang telah diolah, data yang akan terkumpul dilakukan pengolahan dengan tahapan sebagai berikut: a. Editing, b. Pengkodean (Coding) c. Entry d. Tabulating e. Pembersihan (Cleaning) f. Pencatatan (Recording). Kemudian dilakukan penentuan kategori variabel intensitas penyuluhan, variabel pengetahuan dan variabel persepsi dengan skala likert (Riduwan, 2005). Skala likert yang digunakan untuk pengukuran intensitas penyuluhan dan pengetahuan adalah, sangat sering dan sangat tahu (5), sering dan tahu (4), kadang atau ragu-ragu (3), jarang atau kurang tahu (2), tidak pernah atau tidak pernah tahu (1). Pengkategorian persepsi adalah sangat setuju (5), setuju (4), cukup setuju (3), tidak setuju (2) dan sangat tidak setuju (1). Setelah dilakukan penilaian atau pengukuran menggunakan skala likert pada setiap jawaban responden, kemudian dilakukan penjumlahan 40 total skor jawaban untuk mengetahui persepsi peternak terhadap peternak pada penggunaan serbuk daun nangka sebagai obat cacing pada domba. Adapun cara menganalisis data deskriptif adalah dengan bantuan garis kontinum yaitu sebagai berikut: Nilai indeks minimal $=$ Nilai terendah $\mathrm{x}$ Jumlah pertanyaan $\mathrm{x}$ Jumlah Responden; Nilai indeks maksimal $=$ Nilai tertinggi $\mathrm{x}$ Jumlah pertanyaan $\mathrm{x}$ Jumlah Responden; Jarak interval $=$ Nilai maksimal-Nilai minimal 5 (Kriteria).

Analisis jalur merupakan pengembangan dari analisis regresi berganda yang dilakukan pengolahan data berkali-kali, sehingga analisis regresi dapat dikatakan sebagai bentuk khusus dari analisis jalur (regression is special case of path analysis). Analisis jalur digunakan untuk melukiskan dan menguji hubungan antar variabel yang berbentuk sebab akibat. (Sugiyono, 2011). Penggunaan PATH Analisis yang bertujuan untuk mengetahui pengaruh intensitas penyuluhan dan pengetahuan peternak terhadap persepsi peternak pada penggunaan serbuk daun nangka sebagai obat cacing pada domba, secara matematis model Analisis jalur dapat ditulis sebagai berikut:

$$
\mathrm{Y}=\rho \mathrm{Y} \cdot \mathrm{X}_{1}+\rho \mathrm{Y} \cdot 2 \mathrm{X}_{2}+\varepsilon
$$

Keterangan:

Y : Persepsi Peternak

$\mathrm{X} 1$ : Intensitas Penyuluhan

$\mathrm{X} 2$ : Tingkat Pengetahuan

$\varepsilon$ : Epsilon / Standar Error

Jurnal Penyuluhan | Vol. 17 (01) 2021 | 28 
Model jalur yang akan dianalisis adalah:

Hubungan Langsung:

$$
\mathrm{Y}=\rho \mathrm{Y} \cdot \mathrm{X}_{1}+\varepsilon
$$

Hubungan Tidak Langsung:

$$
\mathrm{Y}=\rho \mathrm{Y} . \mathrm{X}_{1}+\rho \mathrm{Y} \cdot 2 \mathrm{X}_{2}+\varepsilon
$$

\section{HASIL DAN PEMBAHASAN}

Persepsi seseorang dapat diidentifikasi melalui jawaban yang diberikan terhadap pernyataanpernyataan dari kuesioner yang ada, dimana pernyataan tersebut terdiri dari aspek pengetahuan dan aspek intensitas penyuluhan. Hasil tabulasi dan rekapitulasi data yang didapat kemudian dianalisis dan diinterpretasikan. Hal tersebut selaras dengan Purwatiningsih et al., (2018) yang menyatakan manusia dapat bereaksi terhadap situasi eksternal dan internal. Persepsi peternak terhadap pengobatan cacing Haemonchus contortus pada domba dengan menggunakan serbuk daun nangka dapat dilihat sebagai berikut:

\section{Aspek Intensitas Penyuluhan}

Intensitas penyuluhan merupakan data dari jumlah keseluruhan frekuensi peternak dalam memperoleh informasi tentang manajemen usaha domba.

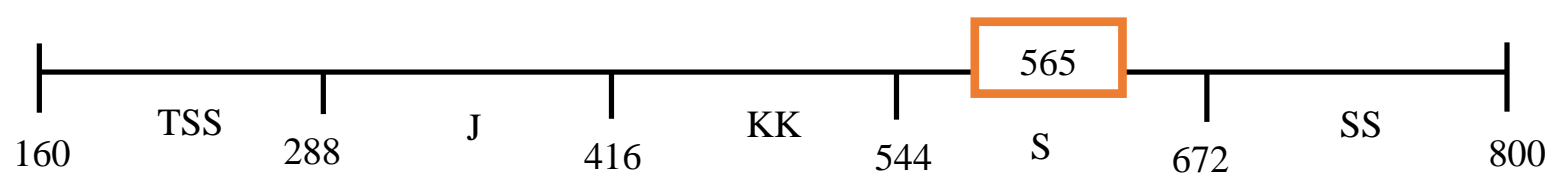

Gambar 1. Garis Kontinum Aspek Intensitas Penyuluhan

Gambar 1 menginterpretasikan bahwa intensitas penyuluhan terdapat pada kategori sering dengan total skor 565. Segala informasi yang didapatkan oleh peternak tidak hanya bersumber dari penyuluh. Namun, dapat juga dari sesama peternak dan media seperti televisi dan radio.

Faktor yang mempengaruhi intensitas penyuluhan yang sering adalah peran penyuluh yang tidak hanya memberikan informasi bidang pertanian namun juga informasi bidang peternakan dalam kegiatan pertemuan rutin sebulan sekali. Namun, kondisi yang seperti ini tidak sesuai dengan kuantitas pelaksanaan kegiatan penyuluhan yang sebaiknya memperoleh minimal 16 kali dalam sebulan (Kementerian Pertanian RI, 2006). Selain itu, peran dari pemanfaatan media seperti televisi dan radio yang akrab dengan keseharian peternak. Faktor yang lainnya adalah peran dari peternak domba yang lain, perbedaan pengalaman dalam usaha domba memungkinkan peternak lain memberi motivasi atau informasi terkait komoditas domba

\section{Aspek Pengetahuan}

Pengetahuan adalah serangkaian dari seluruh pemikiran, gagasan, ide, konsep serta pemahaman yang dimiliki oleh peternak.

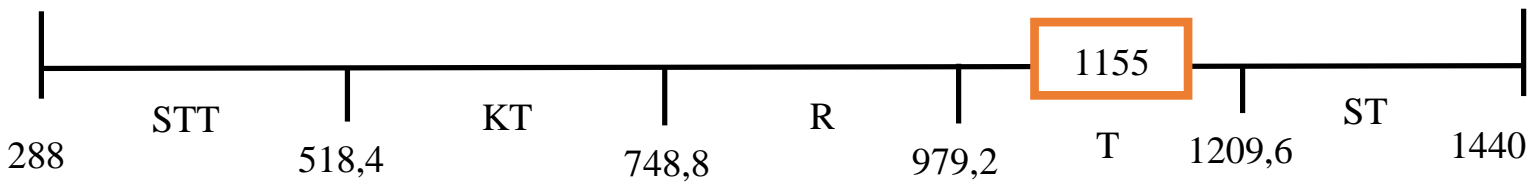

Gambar 2. Garis Kontinum Aspek Pengetahuan

Berdasarkan Gambar 2. dapat diketahui bahwa pernyataan dari aspek pengetahuan memiliki tanggapan yang bervariasi. Total nilai dari aspek pengetahuan sebesar 1155 yang mana nilai tersebut masuk 
dalam kategori tahu. Peran penting pengetahuan peternak di setiap sektor pengambangan peternakan adalah bahwa pengetahuan tersebut diperoleh dari pengalaman peternak itu sendiri secara langsung. Pengalaman ini didapat melalui panca indera baik mata, telinga maupun organ lain yang berhubungan langsung dengan penyerapan infromasi (Soekidjo, 2010).

\section{Persepsi}

Persepsi adalah proses identifikasi atau pengenalan suatu yang dianggap baru menggunakan panca indera. Persepsi merupakan suatu proses memberi arti pada stimulus tertentu melalui proses penginderaan dan menghasilkan interpretasi individu atas stimulus yang diterimanya (Widyastuti et al., 2016).

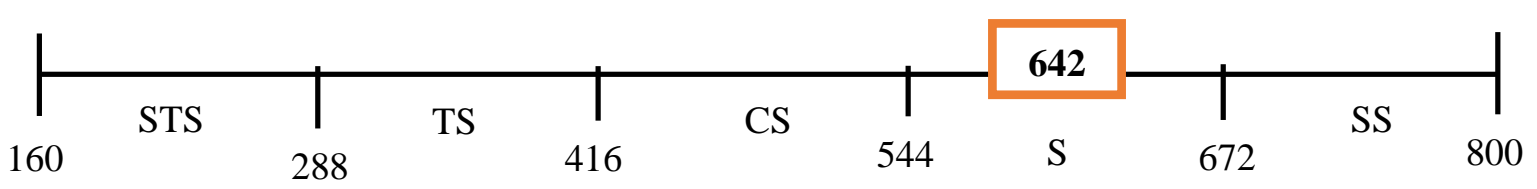

Gambar 3. Garis Kontinum Aspek Persepsi

Berdasarkan Gambar 3 dapat diketahui bahwa persepsi termasuk dalam kategori setuju dengan total skor 642. Dalam hal ini, peternak yang termasuk dalam kategori sangat setuju. Faktor-faktor yang mempengaruhi persepsi peternak adalah tingkat keuntungan dari manajemen budidaya domba yang baik dan penggunaan obat cacing dengan menggunakan serbuk daun nangka, tingkat kenyamanan peternak dalam pengaplikasian pada ternak, kecocokan teknologi dengan kebutuhan peternak, tingkat kerumitan inovasi yang dicoba oleh peternak, serta peningkatan drajat sosial dari pengguna inovasi. Sesuai dengan pernyataan dari Kartika (2015) yaitu faktor yang dapat mempengaruhi persepsi adalah karakteristik dari inovasi itu sendiri (relative advantage, compatibility, complexity, triability, dan observability). Sebagai contoh adalah faktor harga jual dari produk budidaya domba dan diikuti produksi, modal, tenaga kerja, dan luas lahan yang dibutuhkan (Jampur et al., 2019).

Karakteristik internal dari individu atau kelompok sasaran juga merupakan hal penting yang mempengaruhi persepsi. Selaras dengan pernyataan Suharyanto et al., (2018) persepsi petani dipengaruhi oleh budaya bertani, sikap, keyakinan, keberanian beresiko, tingkat pengetahuan, rasionalitas, kerjasama, peran dalam kelompok. Selain karakteristik inovasi, faktor eksternal yang juga mempengaruhi persepsi adalah intensitas penyuluhan atau sosialisasi terkait hal baru atau inovasi yang diberikan kepada sasaran.

\section{Analisis Jalur (Path Analysis)}

\section{Syarat Uji Asumsi}

\section{Uji Normalitas}

Data yang digunakan pada penelitian ini perlu diuji normalitas, dengan tujuan agar data yang digunakan berdistribusi normal (Ghozali, 2016). Pengujian variabel endogen, variabel eksogen, atau keduanya menggunakan uji normalitas, sehingga dapat mengetahui apakah memiliki distribusi data normal atau mendekati normal. Uji normalitas menggunakan Kolmogrov Smirnov dapat dilihat pada Tabel 1 berikut. 
Tabel 1. Hasil Uji Kolmogrov Smirnov

\begin{tabular}{|c|c|c|}
\hline \multicolumn{3}{|c|}{ One-Sample Kolmogorov-Smirnov Test } \\
\hline & & \\
\hline$N$ & & 32 \\
\hline \multirow[t]{2}{*}{ Normal Parameters ${ }^{a, b}$} & Mean & 0,0000000 \\
\hline & Std. Deviation & 2,38285217 \\
\hline \multirow[t]{3}{*}{ Most Extreme Differences } & Absolute & 0,111 \\
\hline & Positive & 0,111 \\
\hline & Negative & $-0,072$ \\
\hline Test Statistic & & 0,111 \\
\hline Asymp. Sig. (2-tailed) & & $0,200^{\mathrm{c}, \mathrm{d}}$ \\
\hline $\begin{array}{l}\text { a. Test distribution is Norma } \\
\text { b. Calculated from data. }\end{array}$ & & \\
\hline c. Lilliefors Significance Cor & & \\
\hline
\end{tabular}

Tabel 1 menunjukan bahwa besarnya nilai Kolmogrov Smirnov adalah 0,111 dengan nilai signifikan 0,200 ( $>0,05$ ). Berdasarkan hasil tersebut dapat dikatakan bahwa model regresi berdistribusi normal. Hasil tersebut sesuai dengan pendapat dari Santoso (2003) bahwa pada nilai Asymp. Sig (2-tailed) memiliki probabilitas di atas 0,05 maka data tersebut berdistribusi normal.

\section{Uji Multikolinieritas}

Tujuan dari pengujian multikolinieritas adalah mengetahui hubungan atau korelasi yang terjadi diantara variabel bebas dalam model regresi (Ghozali, 2016). Kegunaan uji multikolinieritas dalam penelitian ini adalah mendeteksi apakah ada atau tidak penyimpangan asumsi klasik yaitu hubungan liniear antar variabel eksogen dalam model regresi linier tersebut. Hasil uji multikoliniearitas dapat dilihat pada Tabel 2.

Tabel 2. Hasil Uji Multikoliniearitas

\begin{tabular}{llcr}
\hline \multicolumn{1}{c}{ Model } & \multicolumn{2}{c}{ Collinearity Statistic } \\
\cline { 3 - 4 } & & Tolerance & VIF \\
\hline 1 & (Constant) & 0,988 & 1,012 \\
& Intensitas Penyuluhan & 0,988 & 1,012 \\
Pengetahuan & &
\end{tabular}

a. Dependent Variable : Persepsi

Tabel 2 menunjukkan bahwa nilai Tolerance dan Variance Inflation Factor (VIF) dari kedua variabel yaitu intensitas penyuluhan dan variabel pengetahuan dikatakan baik dan tidak ada gejala multikoliniearitas. Pernyataan ini selaras dengan pendapat dari Napitupulu et al. (2017) yang juga menyatakan bahwa jika nilai tolerance $>0,10$ dan $V I F<10$ maka dapat diindikasi tidak adanya gejala pada multikoliniearitas pada sebuah penelitian.

\section{Uji Linieritas}

Tujuan dari uji linieritas adalah mengetahui spesifikasi model yang digunakan dalam sebuat penelitian (Ghozali, 2016). Uji linieritas ditentukan berdasarkan nilai $\mathrm{F}$ atau nilai sig, apabila nilai $\mathrm{F}$ hitung < $\mathrm{F}$ tabel dapat disimpulkan bahwa ada hubungan linier secara signifikan antara variable $\mathrm{x}$ dan $\mathrm{y}$, demikian juga sebaliknya. Menentukan linieritas dengan nilai sig adalah apabila sig > 0,05 maka garis regresi data dikatakan linier atau sebaliknya. Hasil pengujian linieritas dapat dilihat pada Tabel 4. Menurut Ghozali (2016), uji linieritas bertujuan untuk mengetahui apakah spesifikasi model yang digunakan benar atau tidak. Uji linieritas garis regresi yang dilakukan adalah dengan menghitung nilai sig. Jika nilai signifikan > 0,05 maka garis regresi data dikatakan linier dan sebaliknya. Hasil uji linieritas terdapat pada Tabel 3 berikut. 
Tabel 3. Hasil Uji Linieritas

\begin{tabular}{lrr}
\hline & Anova Table & \\
\hline & F & \multicolumn{1}{c}{ Sig } \\
\hline Persepsi * Intensitas Penyuluhan & 0,587 & 0,810 \\
Persepsi * Pengetahuan & 1,602 & 0,564 \\
\hline
\end{tabular}

Sumber: Data Primer Terolah 2020

Hasil uji linieritas pada Tabel 3 menunjukkan bahwa distribusi variabel eksogen yaitu intensitas penyuluhan dan pengetahuan terhadap variabel endogen yaitu persepsi adalah linier dengan nilai signifikan 0,810 dan 0,564 .

\section{Uji Heterokedastisitas}

Penentuan ketidakserasian varian pada residual pengamatan dalam model regresi ditentukan oleh hasil uji heterokedastisitas dengan cara meregresikan variable independent dan nilai mutlak residualnya. Pengujian heterokedastisitas memiliki hasil pada Tabel 4 berikut.

Tabel 4. Hasil Uji Heterokedastisitas

\begin{tabular}{lcr}
\hline \multicolumn{1}{c}{ Model } & T & \multicolumn{2}{c}{ Sig. } \\
\hline (Constant) & 0,191 & 0,850 \\
Intensitas Penyuluhan & 1,278 & 0,211 \\
Pengetahuan & $-0,079$ & 0,937 \\
\hline
\end{tabular}

a. Dependent Variable : RES2

Tabel 4 menunjukkan bahwa signifikansi antara variabel intensitas penyuluhan dan pengetahuan absolut residualnya lebih dari 0,05 dengan nilai signifikan sebesar 0,211 dan 0,937 sehingga dapat dikatakan tidak terjadi gejala heterokedastisitas. Sesuai dengan pendapat Ghozali (2016) yang menyatakan bahwa jika signifikansi antara variabel eksogen dengan absolut residualnya lebih dari 0,05 maka heterokedastisitas tidak terjadi.

\section{Uji Hipotesis}

Regresi Linier Berganda digunakan untuk pengujian hipotesis pada penelitian ini, dengan menggunakan Analisis Jalur atau Path Analysis. Berikut merupakan tahap uji hipotesis :

\section{Konsep Analisis Jalur Tahap 1}

Pada tahap ini akan ditunjukkan pengaruh yang signifikan antara intensitas penyuluhan (X1) terhadap Persepsi (Y). Adapun hasil analisis regresi linier berganda diantaranya :

1) Uji Koefisien Determinasi $\left({ }^{2}\right)$

Uji koefisien determinasi digunakan sebagai upaya mengetahui besar kekuatan model dalam menjelaskan variabel intensitas penyuluhan terhadap variabel persepsi. Berikut merupakan hasil uji koefisien determinasi persamaan 1 terdapat pada Tabel 5 berikut.

Tabel 5. Hasil Uji Koefisien Determinasi Persamaan 1

\begin{tabular}{lrrrr}
\hline \multicolumn{5}{c}{ Model Summary } \\
\hline Model & $R$ & $R$ Square & Adjusted $R$ Square & Std. Error of the Estimate \\
1 & $0,111^{\text {a }}$ & 0,012 & $-0,021$ & 4,02443 \\
\hline
\end{tabular}

a. Predictors: (Constant), Intensitas Penyuluhan

Tabel 5 menunjukkan bahwa koefisien determinasi memiliki nilai $-0,021$ yang artinya variabel Persepsi (Y) tidak dapat dijelaskan oleh variabel intensitas penyuluhan (X1). 
Ghozali (2016) menyatakan bahwa koefisien determinasi $\left(\mathrm{R}^{2}\right)$ digunakan untuk mengukur seberapa jauh model mampu menerangkan variasi variabel endogen di dalam suatu penelitian. Nilai koefisien determinasi yaitu antara nol dan satu. Secara sistematis jika nilai $R^{2}=1$, maka adjusted $R$ square $=1$ sedangkan jika $\mathrm{R}^{2}=0$, maka adjusted $R$ square $=(1-\mathrm{k}) /(\mathrm{n}-\mathrm{k})$. Jika $\mathrm{k}>1$, maka adjusted $R$ square akan bernilai negatif dan tidak berpengaruh (Junaidi, 2010).

2) Uji F (Secara Simultan)

Uji simultan atau uji bertujuan untuk mengetahui pengaruh variabel dari intensitas penyuluhan terhadap variabel pengetahuan. Uji F dapat dilihat pada Tabel 7.

Tabel 6. Hasil Uji F Persamaan 1

\begin{tabular}{|c|c|c|c|c|c|c|}
\hline \multicolumn{7}{|c|}{$A N O V A^{a}$} \\
\hline & Model & $\begin{array}{l}\text { Sum of } \\
\text { Squares }\end{array}$ & $\overline{D f}$ & Mean Square & $F$ & Sig. \\
\hline 1 & Regression & 6,025 & 1 & 6,025 & 0,372 & $0,547^{\mathrm{b}}$ \\
\hline & Residual & 485,881 & 30 & 16,196 & & \\
\hline & Total & 491,905 & 31 & & & \\
\hline
\end{tabular}

Tabel 6 menunjukkan bahwa nilai $\mathrm{F}_{\text {hitung }}<\mathrm{F}_{\text {tabel }}(0,372<2,937)$ dengan nilai signifikansi 0,547 diatas $5 \%(\mathrm{p}>0,05)$, artinya variabel intensitas penyuluhan (X1) tidak berpengaruh nyata terhadap persepsi (Y) peternak. Hal ini disebabkan peternak dalam mendapatkan informasi adalah dari frekuensi penyuluh, peternak lain dan media lain seperti televisi dan radio yang masih kurang. Sesuai dengan pendapat Mwirigi et al. (2009) yang menyatakan bahwa kegiatan penyuluhan perlu ditingkatkan, karena penyuluhan merupakan media yang berhubungan langsung dengan perubahan persepsi, pola pikir, pengetahuan, sikap, dan tindakan seseorang.

3) Uji T (Secara Parsial)

Uji Parsial atau Uji T digunakan untuk menunjukkan pengaruh variabel intensitas penyuluhan terhadap persepsi secara parsial. Uji T pada penelitian ini terdapat pada Tabel 7 berikut.

Tabel 7. Hasil Uji T Persamaan 1

\section{Coefficients $^{a}$}

\begin{tabular}{clccccc} 
& \multirow{2}{*}{ Model } & \multicolumn{2}{c}{$\begin{array}{c}\text { Unstandardized } \\
\text { Coefficients }\end{array}$} & $\begin{array}{c}\text { Standardized } \\
\text { Coefficients }\end{array}$ & $\boldsymbol{T}$ & Sig. \\
& & $\boldsymbol{B}$ & Std. Error & Beta & & \\
\hline 1 & (Constant) & 35,862 & 4,218 & & 8,503 & 0,000 \\
& $\begin{array}{l}\text { Intensitas } \\
\text { Penyuluhan }\end{array}$ & 0,143 & 0,234 & 0,111 & 0,610 & 0,547 \\
\hline
\end{tabular}

a. Dependent Variable: Persepsi

Tabel 7. dapat mendeteksi bahwa besarnya nilai $\mathrm{T}_{\text {hitung }}<\mathrm{T}_{\text {tabel }}(0,618<2,048)$ dengan nilai signifikansi 0,547 diatas $5 \%(p>0,05)$, artinya variabel intensitas penyuluhan tidak berpengaruh nyata terhadap pengetahuan peternak, selaras dengan pendapat Sujarweni (2014) yang menyatakan bahwa jika nilai $\mathrm{T}_{\text {hitung }}>\mathrm{T}_{\text {tabel }}$ maka variabel eksogen $(\mathrm{X})$ berpengaruh signifikan terhadap variabel endogen $(\mathrm{Y})$ begitu sebaliknya.

\section{Konsep Analisis Jalur Tahap 2}

Pada tahap ini dilihat pengaruh antara intensitas penyuluhan (X1), pengetahuan (X2) terhadap persepsi (Y). Adapun hasil analisis regresi linier berganda diantaranya : 
1) Uji Koefisien Determinasi $\left({ }^{2}\right)$

Seberapa jauh kemampuan model untuk menjelaskan variable persepsi peternak merupakan tujuan dari Uji Koefisien Determinasiini. Hasil uji determinasi terdapat pada Tabel 8 berikut.

Tabel 8. Hasil Uji Determinasi Persamaan 2

\begin{tabular}{llrrr}
\hline \multicolumn{5}{c}{ Model Summary } \\
\hline Model & $R$ & $R$ Square & Adjusted $R$ Square & Std. Error of the Estimate \\
1 & $0,486^{\mathrm{a}}$ & 0,236 & 0,184 & 2,46365 \\
\hline
\end{tabular}

a. Predictors: (Constant), Pengetahuan, Intensitas Penyuluhan

Tabel 8 dapat menunjukkan bahwa koefisien determinasi ( $\mathrm{R}$ square) bernilai 0,236 dimana dapat diartikan bahwa variabel persepsi dapat dijelaskan oleh variabel intensitas penyuluhan dan variabel pengetahuan sebesar $23,6 \%$, sedang sisanya yang $76,4 \%$ dapat dijelaskan oleh variabel lain.

2) Uji F (Secara Simultan)

Uji simultan digunakan untuk mengetahui pengaruh variabel intensitas penyuluhan dan variabel pengetahuan terhadap variabel persepsi. Berikut merupakan hasil uji $\mathrm{F}$ dapat dilihat pada tabel 9.

Tabel 9. Hasil Uji F Persamaan 2

\begin{tabular}{lrrrrr}
\hline \multicolumn{5}{c}{ ANOVA $^{\boldsymbol{a}}$} \\
\hline Model & Sum of Squares & Df & Mean Square & \multicolumn{1}{c}{$F$} & Sig. \\
& 54,464 & 2 & 27,232 & 4,487 & $0,020^{\mathrm{b}}$ \\
Regression & 176,018 & 29 & 6,070 & & \\
$\quad$ Residual & 230,481 & 31 & & & \\
$\quad$ Total &
\end{tabular}

a. Dependent Variable: Persepsi

b. Predictors: (Constant), Pengetahuan, Intensitas Penyuluhan

Berdasarkan Tabel 9 dapat diketahui bahwa nilai $\mathrm{F}_{\text {hitung }}>\mathrm{F}_{\text {tabel }}(4,487>2,937)$ dengan nilai signifikansi 0,02 dibawah $5 \%(\mathrm{p}<0,05)$, artinya pengaruh variabel intensitas penyuluhan dan tingkat pengetahuan mempunyai pengaruh nyata terhadap variabel persepsi peternak. Sesuai dengan pendapat Wiratna (2014) bahwa jika nilai $F_{\text {hitung }}$ pada pengujian lebih besar daripada $F_{\text {tabel }}$ variabel eksogen (X) berpengaruh secara simultan terhadap variabel endogen (Y) serta Ghozali (2016) menyatakan bahwa jika nilai sig < 0,05 maka artinya variabel Eksogen (X) secara simultan berpengaruh signifikan terhadap variabel endogen $(\mathrm{Y})$.

3) Uji T (Secara Parsial)

Uji T menunjukkan seberapa jauh variabel intensitas penyuluhan dan pengetahuan terhadap persepsi secara parsial atau individual. Hasil uji $\mathrm{T}$ dapat dilihat pada tabel berikut :

Tabel 10. Hasil Uji T Persamaan 2

\begin{tabular}{|c|c|c|c|c|c|c|}
\hline & \multirow{3}{*}{ Model } & \multicolumn{3}{|c|}{ Coefficients $^{a}$} & \multirow{3}{*}{$T$} & \multirow{3}{*}{ Sig. } \\
\hline & & \multicolumn{2}{|c|}{$\begin{array}{l}\text { Unstandardized } \\
\text { Coefficients }\end{array}$} & $\begin{array}{l}\text { Standardized } \\
\text { Coefficients }\end{array}$ & & \\
\hline & & $\boldsymbol{B}$ & Std. Error & Beta & & \\
\hline \multirow[t]{4}{*}{1} & (Constant) & 8,698 & 4,768 & & 1,824 & 0,078 \\
\hline & Intensitas & 0,039 & 0,144 & $0,0,44$ & 0,272 & 0,788 \\
\hline & Penyuluhan & & & & & \\
\hline & Pengetahuan & 0,328 & 0,112 & 0,479 & 2,935 & 0,006 \\
\hline
\end{tabular}

a. Dependent Variable: Persepsi 
Tabel 11. Ringkasan Hasil Estimasi Parameter Model

\begin{tabular}{lccc}
\hline \multicolumn{1}{c}{ Model } & Koefisien Jalur & S & $\mathbf{R}^{2}$ \\
\hline Persamaan 1 $(\mathrm{X} 1 \mathrm{ke} \mathrm{Y})$ & 0,143 & 0,547 & 0,012 \\
$\mathrm{X} 1\left(\rho \mathrm{X}_{2} \mathrm{Y}\right)$ & & & \\
Persamaan 2 $(\mathrm{X} 1, \mathrm{X} 2 \mathrm{ke} \mathrm{Y})$ & 0,039 & 0,007 & 0,236 \\
$\mathrm{X} 1\left(\rho \mathrm{X} \mathrm{X}_{1}\right)$ & 0,328 & 0,006 & \\
$\mathrm{X} 2\left(\rho \mathrm{X} \mathrm{X}_{2}\right)$ & &
\end{tabular}

Sumber : Data Primer Terolah 2020

Tabel 11 menunjukkan bahwa nilai $\mathrm{T}_{\text {hitung }}<\mathrm{T}_{\text {tabel }}$ aspek intensitas penyuluhan $(0,272<2,048)$ dengan nilai signifikansi 0,788 diatas $5 \%(p>0,05)$, artinya variabel intensitas penyuluhan (X1) tidak berpengaruh secara nyata terhadap variabel persepsi $(\mathrm{Y})$. Kemudian nilai dari $\mathrm{T}_{\text {hitung }}>\mathrm{T}_{\text {tabel }}$ aspek pengetahuan $(2,953>2,048)$ dengan nilai signifikansi 0,006 dibawah $1 \%(\mathrm{p}<0,01)$ artinya variabel pengetahuan (X2) berpengaruh sangat nyata terhadap variabel persepsi (Y). Hasil dari penelitian ini menunjukkan bahwa intensitas penyuluhan melalui tingkat pengetahuan memiliki pengaruh yang signifikan terhadap persepsi peternak pada penggunaan serbuk daun nangka sebagai obat cacing pada domba dengan nilai koefisien jalur pengaruh tidak langsung sebesar 0,367. Hasil yang demikian dapat diartikan bahwa intensitas penyuluhan dan tingkat pengetahuan secara signifikan mempunyai pengaruh tidak langsung dan bersifat positif yang artinya tingkat pengetahuan sebagai penghubung (intervening) terhadap persepsi peternak pada penggunaan serbuk daun nangka sebagai obat cacing pada domba.

Hasil ini berbeda dengan Sugiyono (2014) yang menyatakan bahwa terdapat pengaruh positif yang nyata (signifikan) antara variabel intensitas penyuluhan terhadap persepsi peternak, demikian juga variabel tingkat pengetahuan. Hal ini dapat terjadi karena intensitas penyuluhan semestinya dapat mengubah persepsi peternak dalam pengambilan keputusan. Pengetahuan dan pengalaman peternak tidak berkembang dapat disebabkan karena intensitas penyuluhan yang kurang sehingga cenderung menduga-duga terhadap inovasi yang diberikan.

Berdasarkan hasil penelitian Suharyanto et al. (2018) intensitas penyuluhan merupakan salah satu faktor yang penting untuk proses adopsi suatu inovasi. Penyuluhan yang konsisten dan berkelanjutan semestinya memberi dampak pada penambahan pengetahuan dan wawasan petani dalam menerima inovasi. Transfer pengetahuan secara benar dalam proses penyuluhan menyebabkan perubahan wawasan, pola pikir sistematis, dan informasi kearah yang lebih positif.

\section{Distribusi Koefisien Jalur}

Koefisien jalur didistribusikan kedalam dua persamaan. Persamaan 1 secara tidak langsung yaitu $\mathrm{X}_{2}=$ $\rho \mathrm{X}_{2} \mathrm{X}_{1}+\mathrm{e}_{1}$ dan persamaan 2 secara langsung yaitu $\mathrm{Y}=\rho \mathrm{YX}_{1}+\mathrm{e}_{2}$. Ringkasan hasil estimasi parameter model dapat dilihat pada tabel dibawah ini :

Hasil distribusi koefisien jalur pada persamaan diatas yaitu sebagai berikut:

\section{Koefisien Jalur Persamaan 1}

Berdasarkan persamaan hasil regresi 1 pada bagian tabel coefficients menunjukkan bahwa signifikansi dari X1 = 0,547 lebih besar dari 0,05. Berdasarkan hal ini dapat disimpulkan bahwa regresi persamaan 1 yaitu X1 tidak memiliki pengaruh yang signifikan terhadap Y.

Nilai R square pada tabel Model Summary memiliki nilai sebesar 0,012 yang menunjukan bahwa sebagian pengaruh X1 terhadap Y sebesar 1.2\% dan sisanya 98,8\% adalah kontribusi dari variabel lain yang belum termasuk pada penelitian ini. Sementara itu, nilai e1 dicari menggunakan rumus e $1=\sqrt{ }\left(1-0,012^{2}\right)=0,999$. 
Diagram jalur model struktur persamaan1 pada pada Gambar 4.

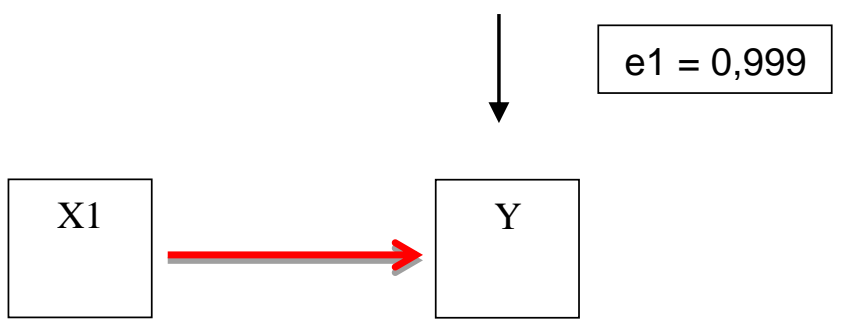

Keterangan: tidak signifikan

Gambar 4. Model Analisis Jalur Persamaan 1

\section{Koefisien Jalur Persamaan 2}

Persamaan kedua pada koefisien jalur ini yaitu $\mathrm{Y}=\rho \mathrm{YX}_{1}+\mathrm{e}_{2}$, dari persamaan tersebut dapat diketahui bahwa pada output regresi persamaan 2 yang di hasilkan pada bagian tabel coefficients nilai signifikansinya adalah sebesar 0,788 (X1) dan 0,006 (X2) terhadap kedua variabel Persepsi. Hal ini menunjukkan bahwa regresi persamaan 2 memiliki pengaruh signifikan yaitu variabel X2 memiliki pengaruh yang signifikan terhadap Y (persepsi). Kemudian, Nilai R square pada tabel Model Summary sebesar 0,236 hal ini dapat menunjukkan bahwa kontribusi X1 dan X2 terhadap Y adalah sebesar $23,6 \%$ dan sisanya $76,4 \%$ adalah kontribusi dari variabel lain yang tidak ada dalam penelitian ini, dan untuk nilai e $1=\sqrt{ }\left(1-0,236^{2}\right)=0,971$. Diagram jalur persamaan 2 ada pada Gambar 5 .

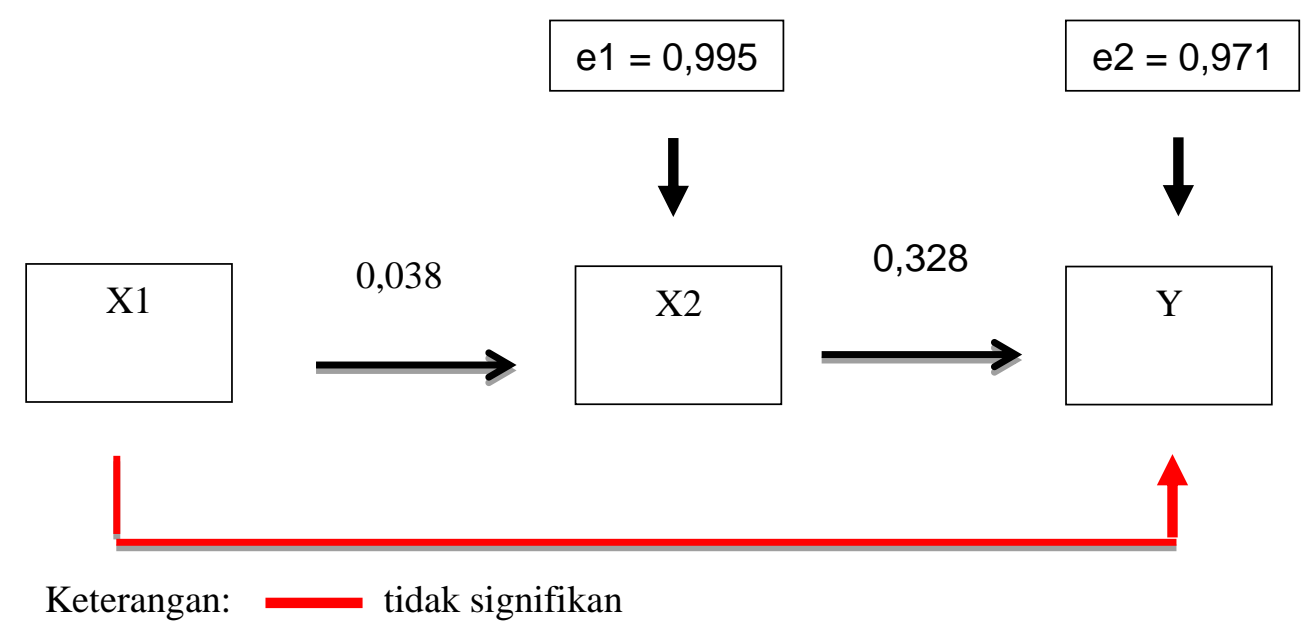

Gambar 5. Model Analisis Jalur Persamaan 2

\section{Menghitung Besarnya Pengaruh}

Tahap ini merupakan perhitungan besarnya pengaruh langsung dan tidak langsung. Hasil analisis dapat diketahui bahwa variabel X1 (Intensitas penyuluhan) dan variabel tingkat pengetahuan memiliki pengaruh yang signifikan terhadap variabel $\mathrm{Y}$ (persepsi), variabel $\mathrm{X} 2$ (pengetahuan) memiliki pengaruh yang signifikan terhadap variabel Y (persepsi) dengan nilai total koefisien jalur 0,366. Hasil ini selaras dengan penelitian Padillah et al. (2018) dengan pernyataan bahwa semakin banyak frekuensi penyuluhan akan meningkatkan interaksi petani dengan penyuluh sehingga dapat membuat tingkat persepsi petani terhadap peranan penyuluh dalam rangka meningkatkan produksi padi akan lebih tinggi. Akan tetapi, hasil perilaku yang dihasilkan dari penyuluhan juga dapat tergantung dari berbagai faktor salah satunya adalah kemampuan dari penyuluh sendiri (Dzakiroh et al., 2017). Karakteristik inovasi dan lingkungan sosial merupakan faktor eksternal yang dapat mempengaruhi persepsi individu (Meijer et al., 2015). 
Kondisi yang demikian terjadi karena intensitas penyuluhan merupakan kegiatan yang sangat diharapkan dapat/bisa mengubah persepsi, pengetahuan dan sikap peternak dalam mengambil keputusan. Berdasarkan hasil penelitian di lapangan diperoleh data bahwa jika intensitas penyuluhan kurang, maka pengetahuan peternak tidak banyak berkembang dan maksimal. Pada kenyataannya banyak peternak yang masi mengabaikan kegiatan penyuluhan, sehingga tidak memaksimalkan potensi SDM yang mereka miliki, serta mau mengembangkan dan meningkatkan pengetahuan mereka masing-masing. Menurut Rahayu et al. (2013), bahwa kegiatan peningkatan intensitas penyuluhan merupakan cara yang efektif dalam meningkatkan pengetahuan peternak itu sendiri, sehingga dengan bertambahnya pengetahuan seseorang, maka hal itu akan memperbaiki sikap dan persepsi terhadap sesuatu.

Hasil bahwa pengetahuan merupakan pengaruh yang penting (signifikan) dalam sebuah pembentukan persepsi masyarakat selaras dengan hasil penelitian (Gampu et al.., 2015). Hasil dari penelitian ini menunjukkan bahwa persepsi dan pengetahuan secara parsial, bersama memberikan dampak yang berarti dan menentukan. Intensitas penyuluhan dapat mempengaruhi seseorang terhadap perubahan persepsinya tergantung pengetahuan yang baik secara teori dan pengalaman orang tersebut, oleh sebab itu, kegiatan penyuluhan yang merupakan sarana bagi peternak untuk memperoleh informasi harus ditingkatkan dengan baik dan terencana.

\section{KESIMPULAN}

Berdasarkan hasil dan pembahasan penelitian yang telah dilakukan, dapat disimpulkan bahwa persepsi peternak terhadap inovasi obat cacing ternak diperoleh nilai sebesar 642 yang artinya peternak berada pada kategori setuju dan memiliki tanggapan yang baik terhadap inovasi yang disuluhkan. Intensitas penyuluhan tidak berpengaruh secara langsung terhadap persepsi, sedangkan pengaruh secara tidak langsung dari intensitas penyuluhan melalui tingkat pengetahuan berpengaruh signifikan terhadap persepsi memiliki nilai koefisien jalur sebesar 0,036 sehingga pengetahuan dapat dikatakan memediasi intensitas penyuluhan terhadap persepsi peternak terhadap penggunaan serbuk daun nangka sebagai obat cacing pada domba.

\section{DAFTAR PUSTAKA}

Amanah, S. (2007). Makna Penyuluhan dan Transformasi Perilaku Manusia. Jurnal Penyuluhan, 3(1), 63-67.

Arikunto, S. (2012). Prosedur Penelitian : Suatu Pendekatan Praktik (Edisi Revisi). In Rineka Cipta.

Dwirayani, D., dan Suciati, T. (2017). Tingkat Persepsi dan Faktor yang Berhubungan dengan Persepsi Masyarakat Terhadap Program Lumbung Pangan Desa (Suatu Kasus di Desa Gegesik Kidul Dan Desa Bayanglangu Kidul. LOGIKA, 21(1), 1-5.

Dzakiroh, D., Wibowo, A., \& Ihsaniyatin, H. (2017). Sikap Afektif Penyuluh Terhadap Website Cyber Extension sebagai Sumber Informasi Penyuluhan Pertanian di Kabupaten Karanganyar. Jurnal Agritexts, 4l(1), 16-31.

Gampu, A.N., L. Kawet, Y. U., Manado, U., Choosing, D., Sulutgo, P. T., Main, B., Manado, B., Ekonomi, F., \& Manajemen, J. (2015). Analisis Motivasi, Persepsi, dan Pengetahuan terhadap Keputusan Nasabah Memilih PT. Bank Sulutgo Cabang Utama Manado. Jurnal EMBA: Jurnal Riset Ekonomi, Manajemen, Bisnis Dan Akuntansi, 3(3), 1330-1340.

Ghozali, I. (2016). Aplikasi Analisis Multivariate dengan Program IBM SPSS 23. (Edisi 8). Semarang: Badan Penerbit Universitas Diponegoro.

Junaidi. (2010). Prosedur Uji Chi-Square. Prosedur Uji Chi-Square.

Kartika, K. (2015). Pengaruh Keragaman Media dan Imbalan Eksternal Terhadap Niat Berbagi Pengetahuan Mahasiswa dan Dosen Akuntansi. Jurnal Akuntansi Universitas Jember, 8(1), 92 95. https://doi.org/10.19184/jauj.v8i1.1224

Kementerian Pertanian RI. (2006). Sistem Penyuluhan Pertanian, Perikanan dan Kehutanan, (2006).

Kusnadi, D. (2011). Metode Penyuluhan Pertanian. STPP: Bogor. 
Marzuki, Saleh. 2010. Pendidikan Non-Formal. DimensiDalam Keaksaraan Fungsional, Pelatihan, dan Andragogi. Bandung:

Meijer, S. S., Catacutan, D., Ajayi, O. C., Sileshi, G. W., \& Nieuwenhuis, M. (2015). The Role of Knowledge, Attitudes and Perceptions in The Uptake of Agricultural and Agroforestry Innovations Among Smallholder Farmers in Sub-Saharan Africa. International Journal of Agricultural Sustainability, 13(1), 40-54.

Muslim. (2016). Varian-Varian Paradigma, Pendekatan, Metode, dan Jenis Penelitian dalam Ilmu Komunikasi. Wahana, 1, No.10(10), 77-85.

Mwirigi, J. W., Makenzi, P. M., \& Ochola, W. O. (2009). Socio-Economic Constraints to Adoption and Sustainability of Biogas Technology by Farmers in Nakuru Districts, Kenya. Energy for Sustainable Development, 13(2), 106-115.

Napitupulu, L. A., Mafis, R., \& Hasan, M. (2017). Pengaruh Komitmen Organisasional, Motivasi Dan Kompetensi Terhadap Kinerja Manajerial Pada Rumah Sakit Swasta Di Kota Pekenbaru. Jurnal Online Mahasiswa Bidang Ilmu Ekonomi.

Narti, S. (2015). Hubungan Karakteristik Petani Dengan Efektivitas Komunikasi Penyuluhan Pertanian Dalam Program SL PTT (Kasus Kelompok Tani Kecamatan Kerkap Kabupaten Bengkulu Utara). Jurnal Professional FIS UNIVED Vol. 2 No. 2 Desember 2015, 2, 40-52.

Novayanti, D., Banuwa, I. S., Safe'i, R., \& Wulandari, C. (2017). Analisis Faktor-Faktor yang Mempengaruhi Persepsi Masyarakat dalam Pembangunan Hutan Tanaman Rakyat pada KPH Gedong Wani. Jurnal Hutan Dan Masyarakat, 9(2), 61-74.

Padillah, P., Purnaningsih, N., \& Sadono, D. (2018). Persepsi Petani tentang Peranan Penyuluh dalam Peningkatan Produksi Padi di Kecamatan Tabir Kabupaten Merangin Provinsi Jambi. Jurnal Penyuluhan, 14(1), 1-10.

Purwatiningsih, N. A., Fatchiya, A., \& Mulyandari, R. S. H. (2018). Pemanfaatan Internet dalam Meningkatkan Kinerja Penyuluh Pertanian di Kabupaten Cianjur. Jurnal Penyuluhan, 14(1), 159-174.

Rahayu, Tri E., Shanti E., dan Ida N. S. 2013. Persepsi Masyarakat Terhadap Biogas Sebagai Energi Alternatif yang Ramah Lingkungan Di Kecamatan Selo, Kabupaten Boyolali. Prosiding Seminar Nasional 2013 Menuju Masyarakat Madani dan Lestari, Fakultas Pertanian UNS.

Santoso, S. (2003). Mengatasi Berbagai Masalah dengan SPSS Versi 11.5. PT Elex Media Komputindo: Jakarta. Soekidjo, N. (2010). Metodologi Penelitian Kesehatan. PT Rineka Cipta: Jakarta.

Sugiyono. (2014). Metode Penelitian Pendidikan pendekatan Kuantitatif, Kualitatif dan R\&D. In METODE PENELITIAN ILMIAH.

Suharyanto, J. Rinaldi, N. N. Arya, K. M. (2018). Faktor-Faktor yang Mempengaruhi Persepsi Petani terhadap Kebijakan Perlindungan Lahan Pertanian Pangan Berkelanjutan di Provinsi Bali. Jurnal Pengkajian Dan Pengembangan Teknologi Pertanian, 20(2), 111-124.

Sujarweni, V. W. (2014). Metode Penelitian: Lengkap, Praktis, dan Mudah Dipahami. Pustaka Baru Press: Yogyakarta.

Sumarno, J., Hipi, A., Handayani, A. W., \& Rouf, A. A. (2019). Peran Penyuluh Pertanian dan Babinsa TNI Menurut Perspektif Petani pada Pelaksanaan Program UPSUS Padi Di Gorontalo. Jurnal Penyuluhan, 15(2), 275-285.

Sunandar, B., Hapsari, H., \& Sulistyowati, L. (2020). Tingkat Adopsi Tanam Jajar Legowo 2:1 Pada Petani Padi di Kabupaten Purwakarta. Jurnal Pemikiran Masyarakat Ilmiah Berwawasan Agribisnis. Juli 2020. 6(2), 500-518.

Sundari, Yusra, A.H.A., N. (2015). Peran Penyuluh Pertanian terhadap Peningkatan Produksi Usahatani di Kabupaten Pontianak. Journal Social Economic of Agriculture, 4(1), $26-31$.

Widiarso, B.P., Wisnu, N., Kurniasih, Joko, P. (2017). Potensi Daun Bambu sebagai Agen Anthelmetika pada Ternak Kambing. Jurnal Pengembangan Penyuluhan Pertanian, 14(25), 
$130-139$.

Widyastuti, Widiyanti, E., S. (2016). Persepsi Petani Terhadap Pengembangan System of Rice Intensification (SRI) di Kecamatan Moga Kabupaten Pemalang. Jurnal Agrista, 4(3), 476-485. 